ARTICLE HISTORY: Received: May 19, 2021 Accepted: July 12, 2021 Published: July 19, 2021

\title{
DEMOCRACY, POLITICAL IDENTITY, AND THE FATE OF MINORITY POLITICS: REFLECTIONS TOWARDS INDONESIA'S NATIONAL CONCURRENT ELECTIONS IN 2024
}

\author{
DR OSBIN SAMOSIR, M.Si \\ Lecturer at Political Science Study Program, \\ Faculty of Social and Political Sciences, \\ Indonesian Christian University, Jakarta.
}

\begin{abstract}
The 2019 and 2014 General Elections in Indonesia was laden with religious identity politics. The election of the DKI Jakarta Governor in 2017 confirmed the politics of religious identity. People were fed up of continuing the democratic process because black and dirty campaigns ruined elections. The Indonesia's democratic posture is getting worse. Presidential candidates were also divided into the Allah party for supporters of Islamic religious identity and the Ibilis party branded for those who opposed.

The principles of democracy, namely respect for human dignity, exclusion of primordial issues, open and fair elections, freedom for voters are actually lost and damage Indonesian democracy. For a long time, the issue of religious identity politics was the most dangerous for democracy and a healthy political process in Indonesia.

How was the fate of Christian politicians in such bad religious identity politics at that time when they were nominated by political parties from strong Islam-based regions? The personal attitude of Christian candidates who can be trusted between their words and deeds, speaking less but doing more is able to transcend fears in the politics of religious identity. This research looks at the 2019 and 2014 General Elections to be a reflection towards the 2024 Simultaneous General Elections through in-depth interviews and literature reviews.
\end{abstract}

Keywords: identity politics, democracy, general elections, Christian politicians

\section{INTRODUCTION}

The practice of bad religious identity politics in the 2019 Presidential Election, the 2017 Jakarta Gubernatorial Election, and the 2014 Presidential Election created fear for the majority of Indonesians. The public was disappointed with the electoral process that has worsened Indonesian democracy. The public was antiphatetic with the electoral process that has aggravated Indonesian democracy. The 2019 and 2014 presidential elections nominated Joko "Jokowi" Widodo and Prabowo Subianto. The 2019 Election was worse than the 2014 Election because it was frightening with its open identity politics, and proceeded chaotically Negative campaigns widely spread against Prabowo Subianto while Jokowi was the target of ablack campaign.

Politics of ethnic, racial, inter-group identity, especially which used the name of religion, contaminated public space during the 2019 and 2014 elections. The party which fights for nationalistic and democratic ideology was face to face with Islamist party, feared to have the agenda to estalish Islamic based-ideology, which struggles to enforce Islamic values. There was fear it was aimed at the establishment of religious state ideology. Whereas the issue of religious identity politics in Indonesian should have finished after the debate son Pancasila as Indonesia's state ideology from 1945 to 1957.

Jokowi lost to Prabowo in 2 nearest provinces to capital city Jakarta in the 2019 and 2014 presidential election, namely Banten Province in the west and West Java in the east. Jokowi failed there because he did not get blessings fanatical Muslim leaders and clerics in those two provinces.

Practice of religious identity politics also occurred in the 2017 Jakarta Gubernatoria Election. Incumbent Governor Basuki "Ahok" Tjahja Purnama, a Christian and a Chinese descent, won the first round of the gubernatorial election. In the second round Ahok however was prosecuted vehemently. Triggered by a slip of the tongue by Ahok on the Holy Quran during a campaign rally in Kepulauan Seribu Regency, Ahok was sentenced to two years prison by the North Jakarta District Court . The sentence was final and binding because both Ahok and prosectors did not appeal to higher court, while election process was still underway. The three consecutive bitter experiences of identity politics were hurtful for voters.

Table 1

2019 Presidential Election

\begin{tabular}{|c|c|c|c|}
\hline & Joko Widodo-Mahruf Amin & Prabowo Subianto-Sandiaga Uno & Difference in Votes \\
\hline Jakarta & $3,279,547$ votes & & $3,279,547$ votes \\
\hline West Java Province & $(51.68 \%)$ & $3,066, .137$ votes & $(51.68 \%)$ \\
\hline Banten Province & $(48.32 \%)$ & Joko Widodo won: & $(48.32 \%)$ \\
\hline
\end{tabular}

(Source: the General Election Commission of Republic of Indonesia 2019) 
The data above explains that in Banten Province, Prabowo-Sandiaga received 4,059,514 votes (61.54\%), far higher compared to 1,521,990 votes (38.46\%) for Jokowi-Ma'ruf pair (Kompas, 2019). Meanwhile in West Java Province, Jokowi-Ma'ruf only won 10,750,568 votes (40.07\%), Prabowo-Sandiaga won 5,326,878 votes (19.86\%) (Republika, 2019). In Jakarta the Jokowi-Ma'ruf pair won narrowly with 3,279,547 votes (51.68\%) from Prabowo-Sandiaga.

The above politics of religious identity raises two questions: First, what is the reason for the strengthening of religious identity in politics in Indonesia? Second, what was about the chance of Christian politicians who were were nominated in strong Islamic areas such as West Java, Banten, Jakarta, South Sulawesi, Riau, East Java, and others.

This working paper is prepared by presenting a general description of people's traumatic experience on religious identity politics, outlining the reasons for the increasingly worrying emergence of religious identity politics, Prabowo's victory in Indonesia's three main provinces, and the progress of Christian politicians in Islamic strongholds. It is concluded with the findings of this paper that identity politics are supported by hardline Muslim leaders in order to create a state with the ideology of the Khilafah, as a serious note for the 2024 simultaneous elections.

The methodology of this working paper uses qualitative research, namely datas from official literature and in-depth interviews with relevant parties. Lately, science community in Indonesia has been increasingly more interested in the field of political studies as an effort to find alternatives from their own cultural treasures to balance the strengths, weaknesses and the applicability of political concepts originating from Western politics (Sulaeman, 2004). Miriam Budiardjo argues that since the mid-1980s, social sciences authority in Indonesia has strongly encouraged efforts by Indonesian scholars to develop political concepts from Indonesia's own cultural treasures (Budiardjo, 1992).

\section{IDENTITY POLITICS CONTAMINATED THE 2019 AND 2014 ELECTIONS}

The practice of identity politics during the 2019 Election left a trail of psychological traumas among voters community, because 4 children died, 172 people were injured, and 74 people were arrested during violent protests in front of the Election Supervisory Agency office (Tirto, 2019). The socio-psychological impact of identity politics, especially in the name of religion, has occurred since the 2014 Election and culminated in the 2019 Election. Minority communities, especially Christians, were fed up with elections that are heavily dominated by religious identity politics.

Lecturer in Political Science from University of Indonesia, Hurriyah, had predicted from the beginning that if the head-to- head duel scenario for the 2019 presidential candidates was repeated, like in the 2014 election, it would have very negative impacts to Indonesia's political conditions. A tense atmosphere occurred in the 2014 Presidential Election, where Jokowi and Prabowo also competed. Very severe contestation occurred in the 2014 Election, causing polarization in the society. Hurriyah suspected there were efforts by a number of parties to continue to maintain this divided condition (Republika, 2018). Because most of political elites only want to get people's votes, without paying attention to the divisive impacts to the society which is difficult to reunite again.

The 2019 and 2014 elections left broad impacts, where politics increased, but the economy deteriorated, and civil society became stagnant in the light of de-monopolization and democracy (Democracy Index, 2014). Liberalization is still higher than equality, while Indonesia's democracy index is stagnant in bad category with a score of 5.42 on a 10.00 scale (Detiknews, 2014). Compared to previous election, the result of the 2014 election showed a change of political constellation. The Indonesian Democratic Party of Stuggles (PDI Perjuangan) won the legislative election but there was no majority power in the parliament.

Competition during the Presidential Election resulted in the polarization of two political blocs. This has an impact on the increasing intensity of political discussions in the public space, the politicisation of citizen participation, and political education (Anugerah, 2014).

Community's psychological trauma emerged from to rampant black campaigns since the 2014 Presidential Election , with the using social media by the two presidential candidates (Litbang Kompas, 2014). For example, the presidential election campaign period from June 4 to July 5, 2014 ,became a hot" battleground" before the July 9 voting day. For the sake of gathering more votes, even before campaign period began, black campaign practices had been rampant to attrack voters.

Black campaign and negative campaign pattern with issues of ethnicity, religion, and race were used by the supporters of the two presidential candidates through social media and traditional media to bring down political opponents by attacking the presidential candidate personally. Subject matters to criticize the presidential candidates' ideas, vision and mission, and programs did not appear at all. The daily newspaper Kompas Research and Development poll in 2014, on the phenomenon of the rampant black campaign proved that almost 50 percent of respondents considered personal attacks on the presidential candidates had been too excessive. Black campaign is expected to create a bad impression in the minds of the people about the future leaders of the nation before they making up their mind.

Hatred provoking campaign materials resulted in very low public interest to be involved in the presidential election campaign activities. Two out of three respondents expressed no interest in participating in the campaign rallies even when they were organized by the presidential candidate of their choice. The 2014 KOMPAS newspaper poll showed 64.0 percent of respondents believed the increasingly massive black campaigns had provoked open conflicts among the supporters of the two candidates.Tabloid OBOR RAKYAT People's Torch tabloid), which only appeared during the 2014 presidential election, had become a bad megaphone for certain parties because it presented false and baseless news against the candidate Joko "Jokowi” Widodo (Tempo, 2018). 
More than half of respondents (58.3\%) were worried that black campaigns were threatening to the unity of the nation. This concern rose because the issues raised in the black campaigns involved group sentiments, which was based on primordial and fanatical hatred agaisnt the the presidential candidates. Negative primordial sentiments would trigger hatred against certain groups. If black campaign was allowed to continue without control, the impacts would be far reaching and would be damaging not only to Indonesian democracy but also to the foundations of the Indonesian nation unity.

The London-based BBC international news agency revealed that it was not just because of creative campaigns in the social media, but also beause negative campaigns and even black campaigns were widely spread to erode Jokowi's electabilityfor the advantage of Prabowo.in the 2014 election. According to social media monitoring site Politicawave, Jokowi-Jusuf Kalla pair became the target of black campaign with 94.9 percent percentage and negative campaign 5.1 percent. It was different for Prabowo-Hatta pair with fewer black campaigns, 13.5\%, while the negative campaign reached $86.5 \%$ (Lestari, 2014). Negative campaign against Prabowo Subianto was on old issues such human rights related problem when he was still active in the military, while Jokowi was the target of religious and racial identity politics. It was difficult to find Pak Jokowi's weaknesses, so black campaign was the only way to defeat him.

Still with the same two presidential candidates, the 2019 Presidential Election was even much worse because election campaigns proceeded freighteningly and riots erupted for several weeks in Jakarta. The accusation that President Jokowi did not care at all with the interests of Islam became the loudest voice during the campaign, although his running mate was the chairman of the Indonesian Ulemas Council MUI) KH Mahruf Amin (Wiwoho 2018).

\section{WHY DOES RELIGIOUS IDENTITY POLITICS STRENGTHEN?}

Religious identity politics (Islam) emerges because religious symbols are believed to increase popularity and the level of acceptability by touching the emotional side of the people (Kahmad 2002, Ramlan 2014). This side is used by Islamic extremist groups to achieve their ambition to create an Islamic state ideolog. According to some estimations, the number of supporters of the Khilafah (caliphate) state in Indonesia is currently more than 20 million people as of 2017 (SMRC, 2017). That number is equivalent to 9.2 percent of respondents who agree with the formation of an Islamic state in Indonesia, while 11.5 percent do not know or do not want to answer. And if the two types of respondents are considered to be just the same, the number of those who want a khilafah state or an Islamic state in Indonesia becomes 20.7\% This number could have greatly increased since the 2019 Election, which was heavily dominated by the issue of Islamic religious identity. It should be worrying because the formation of the Khilafah state rejects the existence of the state ideology Pancasila.

The idea of to establish the spirit of Islam in Indonesian state was firstly began in the formulation of a basic philosophy (Philosposhce Grondslag) for Indonesia from May to June 1945, during the General Meeting of BPUPKI (the Indonesian Independence Preparatory Investigation Agency). Muh Yamin, for example, in his presentation conveyed the idea:

"If we impose all the teachings of the Qur'an which are aimed at maintaining the state, then we should prioritize the Asjsiura chapter 38, which says" All of their matters are subject to deliberation". This command is clear and straightforward. Also in the history of the Messenger of Allah and during the time of the fourth chalif, Alchulafaharrasjidun, it is evident that the collective deliberation was carried out as well as possible, so that by implementing this basic principle all ummah or their representatives could participate in the formulation and implementation of the state. " (Yamin, 1945)

The idea to incorporate Islam into the state ideology was increasingly visible in the Ninth Committee Session, on June 22, 1945, which was chaired by Soekarno, where Mohammad Hatta, Agus Salim, Mohammad Yamin, and the Christian Alex Andreas Maramis, agreed to establish the Jakarta Charter. The first principle Pancasila reads as follows "Divinity, with the obligation to carry out Islamic law for its adherents". The reason is because the population who have been Muslim from the past until now has always been close to $90 \%$ of the percentage of the entire population of Indonesia.

According to the official text, the charter mentions that "Indonesia's National Independence shall be laid down in a Constitution of the State of Indonesia, which is to be established as the State of the Republic of Indonesia with sovereignty of the people and based on the belief in the One and Only God, with the obligation to abide by Islamic law for adherents of Islam, on just and civilized humanity, on the unity of Indonesia and on democratic rule that is guided by the strength of wisdom resulting from deliberation / representation, so as to realize social justice for all the people of Indonesia."

The Jakarta Charter was rejected on August 18,1945 after Alex Andreas Maramis, a Christian, raised his objection. Seven words were erased and eventually they read: "Belief in the one and only God". The most intense ideological debates took place for a long time (November 1956 to July 5, 1959) during the Constituent Assembly between Islamic bloc versus Nationalist bloc when they drafted the revision of the 1945 Constitution. The Constituent Assembly ended in failure and President Soekarno issued a Presidential Decree on July 5,1957, to return to the original 1945 Constitution (www.konstitutante, 2020). 
A number of separatist rebellions to establish an Indonesian Islamic state under the Islamic Khilafah, Darul Islam and Islamism occurred in the past including: the Darul Islam (Rumah Islam) DI/TII on August 7, 1949 by Sekarmadji Maridjan Kartosoewirjo in Tasikmalaya, West Java Province, Daud Beureueh rebellion in Aceh Province (1953-1962), Amir Fatah rebellion in Central Java Province (1950-1959), and Kahar Muzakkar rebellion in South Sulawesi Province (1950-1965). The autrhoritarian New Order government (1966-1998) with its authoritarian government did not experience rebellions to establish an Islamic state because President Soeharto acted firmly and brutally.

\section{Islamic ideology Intensifies inthe Reformation Era}

Why did Islamic religious identity issues become very strong and worrying in the 2019 and 2014 elections? It was initially triggered by the rise of Jokowi from the Mayor of Solo, in Central Java ,to become a candidate of Governor of Jakarta, pairing with Basuki "Ahok) Tjahja Purnama, a Christian and Chinese descent, in 2012. Both were nominated by PDI Perjuangan chairwoman Megawati Soekarnoputri and Gerindra (Great Indonesian Movement) chairman Prabowo Subianto. For the first time, there was a Christian as deputy governor of Jakarta for 2012-2017 period.

Jokowi's phenomenal blusukan (impromptu visit ) practice had skyrocketed his name throughout the country. In 2014, Jokowi was nominated by the PDI Perjuangan as its presidential candidate against Gerindra Party chairman Prabowo Subiant, who supported him in the 2012 Jakarta Gubernatorial Election. Jokowi was accused of having bad political ethics because he was not responsible to complete his 2012-2017 term as Jakarta governor. Jokowi won the 2014 presidential election.

Ahok, a Christian and Chinese Indonesian, who resigned from the Gerindra Party after becoming deputy governor, automatically became governor of Jakarta, following Jokowi's victory in the presidential election. Hatred against Ahok culminated soon. He was accused of having bad political attitude, poor moral, and rude. Of course the anti Ahok movement could not be separated from his ethnic and religion background.. Gerindra party, the Islamist Prosperous Justice Party (PKS) and Muslim extremist leaders rallied supports to oust Ahok. PKS performed well in Jakarta. In 2004, it gained most seats at the Jakarta Legislative Council, and it was the second or third winner in the 2009, 2019 and 2014 elections. (www.kpuri, 2020).

It was unavoidable that religious identity which had been inflaming in the 2014 Presidential Election became more intense in the second round of the 2017 Jakarta Gubernatorial Election, where Ahok faced Anies Baswedan, who was fired by Jokowi as Minister of Education, reportedly due to his poor permance.Ahok was brought to trial on charges of blasphemy against Quran when he campaigned in Kepulauan Seribu (Thousand Islands) Regency. More than a million Muslims took to the Jakarta streets on Friday, December 2,2016 (known later as 212 Movement), demanding the trial of Ahok. Ahok was later found guilty and sentenced to two-year in prison by North Jakarta District Court. Ahok's trial become the nativity of Islamic social movement to guard the blasphemy legal process. (Fuqoha-Sukendar, 2018).

The 212 Action Movement as a movement to defend Islam strongly determined the choice of the umma (believers) in regional, legislative, and presidential elections (Bonasir, 2018). The collective behavior of Islamic social movements was caused by the aspiration among Muslims which required aggressive-progressive movements because Islamic organizations so far tended to move conventionally (Mustofa, 2018). Islamic political parties are busy with problems of their internal interests. The government seems to ignore the asspirations of Muslims, and therefore they need to find their own answer (Sembiring, 2018).

In the 2019 Presidential Election, clerics and activists held their second congregation, called Ijtima Ulama II 212, and issued a recommendation for the ummah and parties to choose Prabowo-Salem Segaf (the supreme leader of PKS) or Prabowo-Muslim preacher Abul Somad as their candidate in the 2019 presidential election. In the 2019 Presidential Election, bad religious image and identity was affixed to the two presidential candidates, namely Allah's Party and Satan's Party. Former Chairman of Muhammadiyah, Amien Rais, promoted the two categories in the the \# 2019ChangePresident movement. Jokowi belonged to Satan party while Prabowo belonged to Allah's Party. (Kurniawan, 2018).

This is an excerpt from Amien Rais' statement (www.cnnindonesia, 2018):

"Currently, we should mobilize all national forces to join and form a party. Not just PAN (National Mandate Party) PKS, Gerindra, but a group that defends the religion of Allah, namely Hizbullah. Against whom? To fight the hizbusy syaithan (Satatnic Party), anti God people automatically join big party, the Satanic Party Do you know that the satanic party must be inhabited by people who lose the world now and lose it in the hereafter ... But in another place, the believers join a large party called Hizbullah, the Party of Allah. The party that wins the war and reaps the glory."

In the 2019 Presidential Election, Rizieg Shihab, the Grand Imam of the extremist Islamic Defenders Front (FPI), spread a dichotomy between the Axis of Mecca and the Axis of Beijing. The terms of Mecca and Beijing have discriminatory connotation and stigma. The terminology of the Mecca Axis implies the meaning of Islamist, religious and vision of change (Koning, 2018). The terminology of the Beijing Axis was aimed to stigmatize "Chinese" sentiment for supporters of President Jokowi. Anti-Chinese sentiment was very high during the criminalisation and imprisonment of Ahok, the Jakarta governor (Friana 2017, Kresna 2017).

As the result of black campaigns during the 2019 Presidential Election, Prabowo won a landslide victory in the areas where former separatist Darul Islam was based, an organization that fought to create a Islamic sharia state. There is stigma that people who voted for Prabowo are hardlines, radical, and intolerant. Prabowo dominated the votes in 
Sumatra, especiallyin West Sumatra and Aceh with 85.03 percent and 83.11 percent, respectively. In Banten, West Java and South Sulawesi, Prabowo won 62.56 percent, 59.98 percent and 58.48 percent of the votes, respectively. What did Christian politicians do when they have to be placed in strong Islamic-based constituencies?

\section{THE NEMESIS OF CHRISTIAN POLITIANS IN ISLAMIC STRONGHOLDS}

What was the fate and condition of Christian politicians amid the very tense Islamic identity politics during the 2019, 2017 and 2014 elections, especially those who were nominated in strong Islamic regions such as West Java, Jakarta, East Java, South Sulawesi and Riau? And what will happen to them in the 2024 elections? In the two Legislative General Elections (2019 and 2014) in Indonesia, Christian legislators won quite significant seats. West Java Province always gave notable legislative seats for Christian candidates.

Table 2

List of Islamic stronghold provinces and Christian Legislative candidates in the 2014 Elections.

\begin{tabular}{|c|c|c|c|c|c|c|}
\hline \multirow{2}{*}{ PROVINCE } & \multicolumn{6}{|c|}{ POLITICAL PARTIES } \\
\hline & PDIP & Demokrat & Gerindra & Golkar & Nasdem & TOTAL \\
\hline & 6 & - & - & - & - & 6 seats \\
\hline WEST JAVA & 5 & - & - & - & - & 5 seat \\
\hline JAKARTA & 4 & - & 1 & - & - & 5 seat \\
\hline EAST JAVA & 2 & 2 & 2 & 1 & 1 & 8 seat \\
\hline NORTH SUMATERA & 2 & - & - & - & - & 2 seat \\
\hline RIAU & 2 & - & 2 & - & - & 4 seat \\
\hline & 21 seats & 2 seats & 5 seats & 1 seat & 1 seat & TOTAL \\
\hline
\end{tabular}

If we look into the 2014 Legislative Election above, the biggest seats for the secular nationalist PDI Perjuangan came from West Java with 6 seats, 5 seats from Jakarta and 4 seats from East Java. Table 2 and Table 3 explain that the PDI Perjuangan as a nationalist party has always been a political party that contributes seats to Christian legislative members in at least 6 provinces that are based on Islam or at least the majority are predominantly Muslims.

Tabel 3

List of Muslim-based Provinces, where Christian candidates won seats in the 2019 Legislative Election

\begin{tabular}{|c|c|c|c|c|c|c|}
\hline \multirow{2}{*}{ PROVINCE } & \multicolumn{7}{|c|}{ POLITICAL PARTIES } \\
\cline { 2 - 7 } & PDIP & Demokrat & Gerindra & Golkar & Nasdem & TOTAL \\
\hline NORTH SUMATERA & 5 & 2 & - & 1 & 1 & 9 seats \\
\hline JAKARA & 7 & - & - & 1 & - & 8 seats \\
\hline CENTRAL JAVA & 6 & - & 1 & - & - & 7 seats \\
\hline WEST JAVA & 4 & - & - & - & & 4 seats \\
\hline EAST JAVA & 3 & - & 1 & - & - & 4 seats \\
\hline RIAU & 2 & - & - & - & - & 2 seats \\
\hline & 27 seats & 2 seats & 2 seats & 2 seats & 1 seat & SUM: \\
\hline
\end{tabular}

In the 2019 Legislative Election, PDIP remained as the largest contributor of seats and it even increased from 21 to 27 seats in the 2019 elections. North Sumatra Province became the second largest contributor with 9 seats, followed by Jakarta with 8 seats. If a comparison is made between the roles and involvement of Christian figures and contemporary Christian figures in Indonesia in the past and now, there is a strong assumption that the role and involvement of Christians in politics are more real, strong enough, and relatively influential in the past than at present (Silalahi, 2009).

Whereas in terms of percentage, the number of Christians (both Protestants and Catholics) is only small, but politically it has an equal recognition with the majority Muslim population. It was a form of equality in a mature democracy. (Dahl, 2001). The following shows the percentage of Indonesian population based on religion (BPS, 2008):

- Islam : : 192,932,919 people $(88.8 \%)$

- Christians Protestants $\quad: 12,395,753$ people (5.7\%)

- Catholics $\quad: 6,563,199$ people $(3.0 \%)$

- Hindus $\quad: 3,698,282$ people $(1.7 \%)$

- Buddha $\quad: 1,306,248$ people $(0.6 \%)$

- Confucius $\quad: 205,808$ people $(0.1 \%)$

- Others $\quad: 243,931$ people $(0.1 \%)$

$==================$

Total : 217,346,140 people (100\%)

Total population of Christians (Catholics and Protestants) are 18,958,952 people or (8.7\%). So Christians actually should get the seats of $8.71 \%$ of the votes contested in every election. How was the result of the Legislative Election? 
Table 4

Christian seats from the 2019 Legislative Election

\begin{tabular}{|c|c|c|c|c|}
\hline Eleciton 2014 & Name of Party & Number of seats & $\%$ seat & Information \\
\hline Christian Party & - & - & - & \multirow{8}{*}{$\begin{array}{c}\text { Total: } 575 \text { seats }(100 \%) \\
\text { Ratio: } \\
\text { - Christian population: } 8.71 \% \\
\text { - Legislative Christian seats: } 14.43 \% \\
\text { - Difference: } 5.72 \%\end{array}$} \\
\hline \multirow{7}{*}{ Non Christian Party } & PDI Perjuangan & 48 & $8,35 \%$ & \\
\hline & NASDEM & 12 & $2,09 \%$ & \\
\hline & GOLKAR & 8 & $1,39 \%$ & \\
\hline & GERINDRA & 6 & $1,04 \%$ & \\
\hline & DEMOKRAT & 5 & $2,36 \%$ & \\
\hline & PAN & 2 & $0,35 \%$ & \\
\hline & PKB & 2 & $0,35 \%$ & \\
\hline TOTAL & & 83 seats & $14,43 \%$ & \\
\hline
\end{tabular}

Table-4 data shows the percentage of seats won by Christian legislative candidates increased from $12.5 \%$ in 2014 to $14.43 \%$ in the 2019 Legislative Election. In the 2019 Election, PDI Perjuangan dominated the seat gain for Christian legislative members. namely 48 seats $(8.35 \%)$. This again increased sharply compared to the 2014 General Election which won only 35 seats $(6.25 \%)$. The Nasdem Party jumped sharply to get 12 seats $(2.09 \%)$ in second place after PDI Perjuangan, compared to the 2014 Election which only won 3 seats $(0.54 \%)$.

It is noteworthy that two moderate Islamic-based parties in the 2019 Legislative Election, PAN (Natonal Mandate Party) and PKB (National Awakening Party) gave 4 seats $(0.70 \%)$ for Christian candidates. This means a number of Christian parliamemnt members also come from Islamic religious-based parties.

Tabel 5

Seats for Christians in the Legislative Election 2014

\begin{tabular}{|c|c|c|c|c|}
\hline Eleciton 2014 & Name of Party & Number of Seats & $\%$ Seat & Information \\
\hline Christian Party & - & - & - & \\
\hline \multirow{5}{*}{ Non Christian Party } & PDI Perjuangan & 35 & $6,25 \%$ & \multirow{2}{*}{ Total: 560 seats (100\%) } \\
& GERINDRA & 11 & $1,96 \%$ & Christian seats: $11.96 \%$ \\
\cline { 2 - 4 } & DEMOKRAT & 11 & $1,96 \%$ & \\
\cline { 2 - 4 } & GOLKAR & 7 & $1,25 \%$ & Ratio: \\
\cline { 2 - 4 } & NASDEM & 3 & 0,54 & - Christian population: $8.71 \%$ \\
\cline { 2 - 4 } & HANURA & 3 & $0,54 \%$ & - DPR Christian seats: $12.50 \%$ \\
- Difference: $3.79 \%$
\end{tabular}

The data above shows largest number of seats acquired by Christian candidatescame from PDI Perjuangan with 35 seats. Second place is Gerindra Party, who led by Prabowo Subianto, the 2019 and 2014 presidential candidate who won the support of Muslim clerics , especially in West Java., Aceh and West Sumatra

\section{Reasons for Muslim Voters to Choose Christian Candidates}

Amid the tense issue of identity politics 2019 and 2014, what made Muslim voters choose Christian politicians ? We conducted in-depth interviews with a number of Muslim voters. They are Abah Abidin (73 years), Coordinator of Pakorba (Association of New Order Victims) in Sukabumi Regency, Haji Didi Supriadi (56 years), a resident of Mundusari Village, Pusakagara District, Pamanukan-Subang.

The simple conclusion was because the two Muslim voters were impressed by the sincere and kind attitude of the Christian candidates, because of their promises could to be trusted, they acted before speaking, said little but did a lot for the benefit of the people. An honest attitude and not making high promises, and were always present when they community had problems. So it is true when Alan Ware said that if the individual potential is worthselling to voters and is able to raise the votes for political parties, then the role of the party will no longer be dominant (Ware, 1994).

The Muslim voters argument can be categorized into five reasons: First, the ability of the relevant legislative candidates to be well mannered and to win the heart of voters in accordance with local religious and cultural etiquette. Second, the candidate is part of the victims of the Soeharto's 32-year dictatorship. They are related to the outlawed Indonesian Communist Party (PKI), and therefore they garnered support from the New Order's (Soeharto's regime) Victims Association (Pakorba). Third, the willingness of Christian candidates to provide continuous free and regular medical services to the constituents, and not just around the election. Fourth, physical development of public facilities such as mosques, drinking water, and roads. Fifth, the personal ability to approach local figures, especially local government officials togeher with political parties. 
Affan Gaffar's theory that politik aliran (streams politic)s is still powerful in Indonesia as a preference of choice is not fully acceptable anymore. Data from his research in Brobanti area, Yogyakarta, supports the theory that there is a very close relationship between the socio-religious orientation of the individuals and their preference of choice. Data from Brobanti supports the idea that voters' interest to excercise their rights to vote depends on their socio-religious orientation. Santri (student of Islamic boarding school) will be interested to choose an Islamic party, while Abangan (a person who does not strictly practice the teaching of a certain religion) tends to support secular parties in the election. According to Gaffar, the stability of choice preference pattern is clear in this analysis. (Gaffar, 1986) Santri voters seem to be more ideological in making decisions than Abangan. But There is proof that many Muslim voters continue to choose Christian candidates although identity politics are very rampant during the election period.

Ribka Tjiptaning, a Christian woman, a legislative candidate in the 2019 and 2014 elections in West Java Province, was loved and chosen by Muslim citizens, precisely after Ribka publicly admitted that she was the daughter of a Communist Party (PKI) member. According to Clifford Geertz emotial ties will be inseperable when political and primordial aspects are mixed together. Cikolawing Village inhabitants have a strong primordial bond with Ribka, precisely as what Clifford defined. Whereas in Cikolawing Village, Pawenang Subdistrict, around 99.99\% of popolation are Muslims..

Will this kind of experience will repeat in the 2024 simultaneous general elections (legislative, regional and presidential elections) during which open and agressive religious identity politics (Islam) to create an Islamic Khilafah state will occur?

\section{A REFLECTION: TOWARDS THE SIMULTANEOUS 2024 ELECTION}

Political experiences with the striking practice of religious identity politics(Islam) during the 2019 and 2014 general pose a serious threat to the Unitary State of the Republic of Indonesian (NKRI) in the 2024 general elections. As President Jokowi can not be reelected for third term, the winner of the next presidential election will likelycome from the supporters of the Khilafah state establishment. When it happens, the minorities will be increasingly in great danger, and the basic values of democracy, which respect human dignity regardless of their ethnicities and religions, will be more difficult to grow healthily in Indonesia.

The paper proposes the need for further research in a number of other areas to test the assumption that identity politics is actually growing in Indonesia. For example, whether Muslim candidates can wini $\mathrm{n}$ the predominantly Cristian bases. Broader studies on democracy are needed, including in finding out how will be the future of Indonesian democracy in the 2024 elections and in the future after the very practices of identity in the two previous election?*****

\section{DEEP INTERVIEW:}

\section{R E F E R E N C E S}

In-depth interview with a community leader named Abah Abidin is a very influential traditional and community leader, the main supporter of Mrs. Ribka Tjiptaning, a Christian woman member of the Indonesian Parliament from West Java Province in 2009, 2014 and 2019 in Nagrak District, Sukabumi Regency, West Java on Saturday 7 March 2020.

In-depth interview with Haji Didi, a very influential community figure in Mundusari village, Sumedang Regency, West Java Province on Saturday, March 14, 2020. Haji Didi is a supporter of Maruarar Sirait, a Christian member of the DPR RI in the 2009 and 2014 elections from West Java Province.

\section{BOOKS:}

Almond, Gabriel A., "Sosialisasi, Kebudayaan dan Partisipasi Politik", dalam Mohtar Mas'oed dan Colin MacAndrews (eds.), Perbandingan Sistem Politik, Yogyakarta: Gadjah Mada University Press, 2000,

Gabriel A. dan G. Bigham Powell, Jr., Comparative Politics, System, Process and Policy, second edition, Boston: Little, Brown and Company, 1978

Anderson, Benedict dan Audrey Kahin (eds), Interpreting Indonesia Politics: Thirteen Contributions to the Debate, Cornell Modern Indonesia Project, Ithaca, New York, 1982.

Budiardjo, Miriam, Dasar-Dasar Ilmu Politik, Jakarta: Penerbit PT Gramedia Pustaka Utama, 1993.

Burns, Edward McNall, et al. Western Civilization: Their History and Their Culture. New York: W.W. Norton \& Company, 1984.

Dahl, Robert A. Democrcy and Its Critics. New Haven: Yale University Press, 1989.

, Robert A. On Democracy. New Haven: Yale University Press, 1989

Feith, Herbert, The Decline of Constitutional Democracy in Indonesia, Ithaca and London, Cornell University Press, 1962.

Fuqoha dan Sukendar, "Dinamika Gerakan Sosial Politik Islam Dalam Pemilihan Umum Presiden Indonesia 2019" dalam Proceeding Konferensi Nasional Ilmu Administrasi, (Bandung: STIA LAN Bandung, Oktober 2018)

Fuqoha dan Sukendar, "Dinamika Gerakan Sosial Politik Islam Dalam Pemilihan Umum Presiden Indonesia 2019" dalam Proceeding Konferensi Nasional Ilmu Administrasi, (Bandung: STIA LAN Bandung, Oktober 2018.

Hatta, Mohammad, Kumpulan Karangan (I), Penerbit "Bulan Bintang", Jakarta, 1952. , Mohammad, "Collectivisme Toea dan Baroe", Daulat Ra'yat No. 75, 10 Oktober 1933. 
Hasil Penelitian Indeks Demokrasi Asia: Kasus Indonesia Tahun 2014 oleh Pusat Kajian Politik (Puskapol) UI, dipublikasikan di Pasca Sarjana UI, Jl Salemba Raya, Jakarta Pusat, Jumat (12/12/2014).

Huntington, Samuel P., "Democracy's Third Wave", dalam Bernard E. Brown dan Roy C. Macridis, eds., Comparative Politics: Notes and Readings, $8^{\text {th }}$ edition, Belmont: Wadsworth Publishing Company, 1996.

Kahin, George McTurnan, Nasionalisme dan Revolusi di Indonesia, terj. Ismail bin Muhammad B.A. (Hons), Kuala Lumpur: Dewan Bahasa dan Pustaka Kementerian Pelajaran Malaysia, 1980.

Khan, Rais A., James D. McNiven dan Stuart A. MacKown, An Introduction to Political Science, revised edition, Georgetown, Ontario: Irwin-Dorsey Limited, 1977.

Laffan, Michael. Sejarah Islam di Nusantara (terjemahan oleh Indi Aunullah) (Yogyakarta: Bentang Pustaka, 2015.

Magnis-Suseno SJ, Franz, Mencari Sosok Demokrasi: Sebuah Telaah Filosofis, Penerbit PT Gramedia Pustaka Utama, Jakarta, 1995.

, Franz, "Cita-Cita Kenegaraan Bung Hatta", makalah dalam seminar nasional tentang

Membedah Pemikiran Perjuangan Bung Hatta, Arsip Nasional Republik Indonesia, 14 Agustus 2002.

Maarif, Ahmad Syafii. Islam dalam Bingkai Keindonesiaan dan Kemanusiaan: Sebuah Refleksi Sejarah. Jakarta: Mizan, 2015.

Mazour, Anatole G. dan John M. Peoples, Men and Nations; A World History, $3^{\text {rd }}$ edition, New York: Harcourt

Brace Jovanovich, 1975.

Panji Anugerah. Indeks Demokrasi Asia: Kasus Indonesia Tahun 2014. Jakarta: Pusat Kajian Politik (Puskapol) UI, 2014.

Profil Anggota Dewan Perwakilan Rakyat Dan Anggota Dewan Perwakilan Daerah RI Periode 2014 - 2019. Jakarta: Komisi Pemilihan Umum, 2014.

Profil Anggota Dewan Perwakilan Rakyat Dan Anggota Dewan Perwakilan Daerah RI Periode 2019 - 2024.

Jakarta: Komisi Pemilihan Umum, 2019.

Rauf, Maswadi, "Musyawarah untuk Mufakat: Sebuah Cara Penentuan Kebijaksanaan Politik dalam Pembangunan Politik di Indonesia”, dalam Amir Santoso (ed.), 1997.

Risalah Sidang Badan Penyelidik Usaha-Usaha Persiapan Kemerdekaan Indonesia (BPUPKI) Panitia Persiapan Kemerdekaan Indonesia (PPKI), Jakarta: Sekretariat Negara RI, 1995.

Silalahi, Harry Tjan. "Kader Kristen: Urgensi dan Tantangan", dalam Panggilan Membangun Bangsa dan Negara.Dasar Pedoman dan Arah Keterlibatan Politik Kristen. Jakarta: PDKB Kasih Demi Bangsa, 2009.

Sulaeman. Pemikiran Demokrasi Moh Hatta, [disertasi] (Jakarta: Ilmu Politik UI, 2009).

Surjo, dkk., Djoko, Agama dan Perubahan Sosial: Studi tentang Hubungan antara Islam, Masyarakat, dan Struktur Sosial-Politik Indonesia, Yogyakarta: Pusat Studi Sosial dan Asia Tenggara, UGM, 2001.

Zainuddin, A. R. Pemikiran Politik Islam: Islam, Timur Tengah dan Benturan Ideologi (Jakarta: Penerbit Pensil324, 2004).

\section{JOURNAL, PAPER, MAGAZINE:}

"17 Poin Pakta Integritas Ijtima Ulama II yang disetujui Prabowo" (Laporan dan Kajian Tempo) dalam www.tempo.co, Minggu 16 September 2018.

"Amien Rais Dikotomikan Partai Setan Dan Partai Allah", dalam Laporan CNN di www.cnnindonesia.com pada Jumat 13 April 2018.

"PDIP Menunggu manuver Amiern Rais soal Ganti Presiden 2019”, dalam www.tempo.co pada Minggu 10 Juni 2018.

"Pemilu 2019: Darul Islam Bayangi Bangkitnya Politik Islam di Indonesia" dalam https://www.matamatapolitik.com on May 2, 2019 at 2:51 PM.

Azra, Azyumardi. "Genealogy of Indonesian Islamic Education: Roles in the Modernization of Muslim Society" dalam Heritage of Nusantara, vol. 4, no. 1, 2015.

Azra, Azyumardi. "Network of Ulama in the Haramayn: Connection in the Indian Ocean Region" dalam Studia Islamika, vol. 8, no. 2, 2001.

Badrun, “Gerakan Aksi persaudaraan Islam” dalam www.republika.co.id pada 10 Oktober 2018.

Budi Kurniawan, "Politisasi Agama di Tahun Politik: Politik Pasca-Kebenaran di Indonesia dan Ancaman bagi Demokrasi” dalam Jurnal Sosiologi Agama: Jurnal Ilmiah Sosiologi Agama dan Perubahan Sosial Fakultas Ilmu Sosial dan Politik Universitas Sebelas Maret Vol. 12, No. 1, Januari-Juni 2018/ISSN: 1978-4457 hal 143-144.

Fuqoha, F. et.al, "Gerakan Sosial Islam Diantara Gagasan Demokrasi Konstitusional dan Ancaman Radikalisme di Indonesia” dalam https://journal.iaimnumetrolampung.ac.id, Tahun 2018.

Imaduddin Muhammad, Wildan. "Ormas Islam di Jawa Barat dan Pergerakannya: Studi Kasus Persis dan PUI", dalam ANALISIS, Volume XVI, Nomor 2, Desember 2016 jurnal Sekolah Pascasarjana UIN Syarif Hidayatullah Jakarta.

Kurniawan, Budi. "Politisasi Agama di Tahun Politik: Politik Pasca-Kebenaran di Indonesia dan Ancaman bagi Demokrasi” dalam Jurnal Sosiologi Agama: Jurnal Ilmiah Sosiologi Agama dan Perubahan Sosial Fakultas Ilmu Sosial dan Politik Universitas Sebelas Maret Vol. 12, No. 1, Januari-Juni 2018/ISSN: 1978-4457. 
Lestari, Sri (wartawan BBC). Pertarungan pilpres sengit di media social, BBC Indonesia, pada 5 Juli 2014.

Muhsin Z., Mumuh. "Penyebaran Islam Di Jawa Barat, makalah yang disampaikan dalam Saresehan Nasional "Sejarah Perjuangan Syaikhuna Badruzzaman (1898 - 1972) n pada tanggal 13 Juni 2010 di Pondok Pesantren alFalah, Mekargalih, Tarogong Kidul, Kabupaten Garut Jawa Barat.

R. Antares P, "Perjalanan Ijtima Ulama 1 sempai Ijtima Ulama 3", dalam www.tagar.id . pada 3 Mei 2019. Website, News:

www. tirto.id, 23 Juli 2019.

www.bbc.com, 10 Oktober 2018.

www.bbc.com/indonesia, 21 Februari 2017.

www.detiknews.com, 12 Des 2014.

www.kompas.com, 9 Juni 2014.

www.kompas.com, 15 dan 17 Mei 2019.

www.konstituante.net, 10 Agustus 2020.

www.kpu.go.id, 26 November 2019.

www.kumparan.com, 10 Juni 2018.

www.pilpres.tempo.co, 15 Desember 2018

www.republika.co.id, 3 Mei 2018.

www.republika.co.id, 13 Mei 2019.

www.sindonews.com, 10 Oktober 2018).

www.wikipedia.com, 10 Agustus 2020. 